\title{
RESEARCH ARTICLE \\ A comparative study on the effect of processing (soaking, germination and boiling) on nutritional, antinutritional and functional properties of Citrullus Lanatus (watermelon) seed flour
}

\section{Olajumoke Josephine Matthew ${ }^{1}$, Abubakar Ndaman Saidu ${ }^{1}$, Ali Audu Jigam¹, Ocheme Boniface Ocheme ${ }^{2}$}

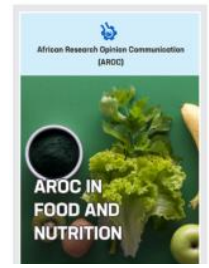

*Correspondence:

Olajumoke Josephine Matthew

Email: jumokemat@gmail.com

${ }^{1}$ Department of Biochemistry, Federal University of Technology, Minna, Nigeria.

${ }^{2}$ Department of Food Science and Technology, Federal University of Technology, Minna, Nigeria

\begin{abstract}
Background: Watermelon (Citrullus lanatus) seed is one of the underutilized crops in Africa. It is a valuable food resource but its usage is limited due to the presence of anti-nutritional factors and its poor storage properties. In this study, the comparative effect of processing methods on nutritional, anti-nutritional and functional properties of watermelon seed flour was determined. Methods; Watermelon seeds were subjected to different processing methods (soaking, germination and boiling), dried and milled into flours. Proximate composition, antinutritional factors (tannins, phytates, oxalate, saponins, trypsin inhibitor, and glycogenic glycoside) and functional properties (water and oil absorption capacity, bulk density, foaming capacity) of the flour were determined using standard methods and analytical procedures. Results: There were significant differences $(p<0.05)$ in the proximate contents between different processing methods. The value of protein content of the seed flours ranges from $13.25 \pm 1.70-18.77 \pm 0.63 \%$. All the anti-nutritional factors were significantly reduced $(p<0.05)$ in the processed seed flour when compared to the unprocessed seeds flour. Soaking significantly $(p<0.05)$ increased the concentrations of histidine, threonine, valine, lysine, leucine, isoleucine and phenylalanine when compared with the unprocessed sample. However, no significant difference $(p>0.05)$ was seen in arginine, methionine, proline and aspartic acid of all the seed flours. The processed seed flour also exhibited desirable functional properties when compared with the unprocessed seed flour. Conclusion: Soaking, germination and boiling can be used for the reduction of antinutrient contents while improving the nutrient density and bioavailability of water-melon seed flour. Thus the processed seed flour hence may be useful for confectionery products, aerated foods and high nutrient density weaning foods.

Keywords: Watermelon seed flour; proximate; anti-nutritional; functional properties; processing methods Citation: Matthew, O. J. Saidu, A. N., Jigam, A. A., Ocheme, O.B. (2021). A comparative study on the effect of processing (soaking, germination and boiling) on nutritional, antinutritional and functional properties of Citrullus Lanatus (watermelon) seed flour. AROC in Food and Nutrition, 1(1), 22-30, https://doi.org/10.53858/arocfn01012230
\end{abstract}

Received: 25 July 2021, Revised:

\subsection{Introduction}

Globally, malnutrition is a very critical public health problem and is responsible for morbidity and mortality in children below 5 years of age in developing countries [1]. In Nigeria, the high rate of malnutrition recorded among children is a result of an increase in population, poverty, fall in agricultural practices, scarcity, shortage and high cost of animal proteins [2].

These are said to have severe consequences on human well-being by aggravating poverty, irreversible mental damages, and poor growth among children [3]. However, nutrition improvement is the main prerequisite for the reduction of high infant and under-five mortality rates, the assurance of physical growth, social and mental development of children as well as their academic achievement [4]. In view of prevalent food shortages, food scarcity, the high price of protein-rich foods, this research work, focused on the exploitation of underutilized and unconventional plant resources. Some of the underutilized plant seeds may fit well into subsistence agriculture as alternative protein sources [3]. There are many parts of plants available, which are rich in nutrients, one of which is plant seeds. This study will therefore provide more information on the use of underutilized seeds and their inclusion in the diets.

Watermelon (Citrullus lanatus) is a fruit crop, an herbaceous creeping plant belonging to the 
family Cucurbitaceae. It is a vine-like flowering plant. It is a berry having a thick rind (exocarp) and fleshy centre (mesocarp and endocarp), and its mainly propagated by seeds and thrives best in warm areas. It is a tropical plant and requires a lot of sunshine and a high temperature of over $25^{\circ} \mathrm{C}$ for optimum growth [5]. It contains about $93 \%$ water hence named watermelon [6]. The fruit is known to be a good source of lycopene and carotenoid. It helps quench the free radicals that contribute to disease conditions like asthma, atherosclerosis, diabetes, colon cancer and arthritis. It is also high in fibre and citrulline; an amino acid the body uses to make arginine [7].

Previous studies showed that protease inhibitors reduced by $70 \%$, lectin by $79 \%$ and tannin by $69 \%$ in pigeon peas when boiled for eighty (80) minutes but phytate is heat-resistant and not as easily degraded with boiling [8-9]. Soaking has been used to process foods and reduce levels of antinutrients. During germination, water diffuses through the seed coats into the embryo, which has been almost completely dry during the period of dormancy, causing a swelling of the seed; the swelling is often so great that the seed coat is ruptured. Thus with the absorption of oxygen by the seed, energy is made available for growth [10]. The present study was aimed at investigating the effect of different processing methods on the nutritional and anti-nutritional compositions of Citrullus lanatus seed

\subsection{Materials and Methods}

\subsection{Sample collection}

Watermelon seeds were purchased from a fruit market in Madalla, Niger State, Nigeria. The seed was authenticated by Mr Mohammed Dangana at the Department of Plant Biology, Federal University of Technology, Minna, Nigeria. Each of the seeds was divided into four portions and each portion was processed differently.

\subsection{Seed processing}

The seeds were cleaned of stones, sand and other particles and were divided into four portions for different processing (raw seeds, soaked seeds, germinated seeds and boiled seeds).
Boiling: The methods described by Ahamefule et al. [11] and Jimoh et al. [12] were used to prepare the boiled samples. One (1) $\mathrm{kg}$ of the seed sample was subjected to boiling at $100{ }^{\circ} \mathrm{C}$ for 15 minutes at the rate of $1 \mathrm{~kg}$ of the seed to $5 \mathrm{~L}$ of water using a kerosene stove after which water was drained off by means of a $10 \mathrm{~mm}$ sieve. The boiled seeds were spread on hessian sacks for 48 to 72 hours under sunlight until dry. After drying, the seeds were milled and kept in plastic containers at room temperature for further analysis.

Socking: The method described by Saulawa et al. [13] was used to prepare the soaked samples. Briefly, one (1) $\mathrm{kg}$ of the seed sample was weighed into five (5) $L$ plastic container, which was then filled with $5 \mathrm{~L}$ cold water for 24 to 48 hours at room temperature. Water was drained from the soaked seed using a sieve with a mesh size of $10 \mathrm{~mm}$ and the seed were air-dried under the sun for 48 to 72 hours. After drying, the seeds were milled and kept at room temperature in plastic containers for further analysis.

Germination: Germination was achieved as described by Kayembe et al. [14]. Briefly, the seeds were soaked for 24 hours, afterwards, they were spread indoors on hessian sacks on the floor, covered with aluminium foil to exclude light, and were allowed to germinate for three days. Water was applied once daily to provide moisture during sprouting. Thereafter, the germinating seed was dried for 48 to 72 hours under sunlight, ground and then kept at room temperature pending further analysis.

\subsection{Determination of proximate compositions}

The proximate including; crude fibre, moisture, ash, and crude fat were determined using standard procedures [15]. Kjeldahl Method was used to determine the nitrogen $(\mathrm{N})$ concentration of the sample. The percentage of $\mathrm{N}$ and protein contents were calculated as follows:

$\% \mathrm{~N}=\mathrm{F} \times($ Titration - Blank $) \times 100$

Where $\mathrm{F}=$ factor associated with the strength of the $\mathrm{H}_{2} \mathrm{SO}_{4}$

Percentage crude protein (CP) was calculated as follows: $\% \mathrm{CP}=\% \mathrm{~N} \times 6.25$ 
The carbohydrate contents were calculated using the formula: \% Carbohydrate $=100-$ ( $\%$ moisture $+\%$ ash $+\%$ protein $+\%$ fat $)$ [16].

\subsection{Determination of antinutritional factors}

The alkaline picrate method was used in the determination of cyanogenic glycoside content of the seed [16]. Phytate, oxalate and saponins contents were determined using the standard protocol of A.O.A.C [17], while the Folin Denis Spectrophotometric method as described by Onwuka [16] was employed to determine the tannins content of the samples. The tannin content was calculated as follows:

$\%$ Tannin $=$ At $/$ As $\times C \times 100 / \mathrm{W} \times \mathrm{Vf}$

Where At $=$ absorbance of a test sample, As = absorbance of standard solution. $\mathrm{C}=$ concentration of standard solution, $\mathrm{W}=$ weight of sample, $\mathrm{Vf}=$ total volume of extract.

\subsection{Determination of functional properties}

Water and oil absorption capacity: The method of Sosulski et al. [18] was used to determine the water and oil absorption capacity of the flours. Water absorption was examined as percentage water-bound per gram flour. The sample $(1 \mathrm{~g})$ was dissolved in distilled water $(10 \mathrm{ml})$ and allowed to stand for 30 minutes at ambient temperature (30 \pm $2{ }^{\circ} \mathrm{C}$ ), centrifuged for 30 minutes at 3000 rpm. The oil absorption capacity of the flours was expressed as percentage oil bound per gram flour. The sample $(1 \mathrm{~g})$ was mixed with $10 \mathrm{ml}$ soybean oil (Sp. Gravity 0.9092) and allowed to stand for 30 minutes at ambient temperature $\left(30 \pm 2{ }^{\circ} \mathrm{C}\right)$, then centrifuged for 30 minutes at $300 \mathrm{rpm}$.

Emulsion activity and stability: The method described by Yasumatsu et al. [19] was used to determine emulsion activity and stability. For emulsion, $1 \mathrm{~g}$ sample, $10 \mathrm{ml}$ distilled water and $10 \mathrm{ml}$ soybean oil were prepared in a calibrated centrifuged tube. The emulsion was centrifuged for 5 minutes at 300 $\mathrm{rpm}$. The ratio of the height of the emulsion layer to the total height of the mixture was calculated as emulsion activity. The emulsion stability was estimated after heating the emulsion contained in the calibrated centrifuged tube at $80^{\circ} \mathrm{C}$ for 30 minutes in a water bath, cooling for 15 minutes under running tap water and centrifuging at $2000 \mathrm{~g}$ for 15 minutes. The emulsion stability was expressed as the ratio of the height of the emulsified layer to the total height of the mixture. Emulsifying activity $=$

Height of emulsified layer $\times 100$. Height of total contents in the tube

Bulk Density: the method described by Jones et al. [20] was used to determine the bulk density. One hundred $(100 \mathrm{~g})$ of the flour was measured in a $250 \mathrm{ml}$ measuring cylinder, the apparent (bulk) density was calculated after tapping the cylinder on a wooden plank until no visible decrease in volume was noticed, and based on the weight and volume.

Swelling Capacity: The method described by Okaka et al. [21] was used to determine swelling capacity. Briefly, $100 \mathrm{ml}$ graduated cylinder was filled with the sample to $10 \mathrm{ml}$ mark. Distilled water was added to give a total volume of $50 \mathrm{ml}$. The top of the graduated cylinder was tightly covered and mixed by inverting the cylinder. The suspension was inverted again after 2 minutes and was left to stand for a further 8 minutes and the volume occupied by the sample was taken after the eighth minute.

Foam capacity (FC) and foam stability (FS): The procedures reported by Narayana et al. [22] were used to determine the foam capacity (FC) and foam stability (FS). The flour sample $(1 \mathrm{~g})$ was added to distilled water $(50 \mathrm{~mL})$ in a graduated cylinder at $30 \pm 2^{\circ} \mathrm{C}$. The suspension was made to foam after been mixed and shaken for $5 \mathrm{~min}$. The volume of foam at $30 \mathrm{sec}$ after whipping was expressed as foam capacity using the formula:

Foam capacity (\%): $\frac{\text { AW-BW }}{\text { BW }} \times 100$

Where, $A W=$ volume of foam after whipping, $\mathrm{BW}=$ volume of foam before whipping

\subsection{Statistical Analysis}

\subsection{Results}

\subsection{Effect of processing methods on proximate compositions}

The proximate compositions of both processed and unprocessed Citrullus lanatus (Water melon) are shown in table 1 . The value of protein content of the seed ranges from $13.25 \pm 1.70 \%$ to $18.77 \pm 0.63 \%$. However, there were significant differences $(p<0.05)$ in 
the protein, ash, fat, carbohydrate contents between different processing methods (raw, soaked, germinated and boiled).

\subsection{Effect of processing methods on ant- nutritional compositions}

The concentrations of the anti-nutritional factors (tannins, phytates, oxalate, saponins, trypsin inhibitor, and glycogenic glycoside) in the processed and unprocessed Citrullus lanatus seed flour are shown in table 2. All the anti-nutritional factors were significantly higher $(p<0.05)$ in the raw flour when compared to the processed seeds.

\subsection{Effect of processing methods on amino acid compositions}

Leucine is the most abundant essential amino acid in all the seed flours while glutamic acid is the most abundant non-essential amino acid. Soaking significantly $(p<0.05)$ increased the concentrations of histidine, threonine, valine, lysine, leucine, isoleucine and phenylalanine when compared with the unprocessed sample. However, no significant difference $(p>0.05)$ was seen in arginine, methionine, proline and aspartic acid of all the seed flours (Table 3)

Table 1: Proximate composition of processed and unprocessed Citrullus lanatus (water melon) seed flour.

\begin{tabular}{|c|c|c|c|c|}
\hline Proximate & WMS & WMG & WMB & WMR \\
\hline Moisture & $0.04 \pm 0.28^{\mathrm{a}}$ & $1.26 \pm 0.01^{\mathrm{b}}$ & $0.31 \pm 0.02^{\mathrm{a}}$ & $3.56 \pm 0.03^{\mathrm{c}}$ \\
\hline Ash & $3.83 \pm 0.09^{\mathrm{b}}$ & $4.45 \pm 0.02^{\mathrm{c}}$ & $4.93 \pm 0.23^{\mathrm{d}}$ & $1.70 \pm 0.15^{\mathrm{a}}$ \\
\hline Carbohydrate & $40.41 \pm 0.77^{\mathrm{a}}$ & $38.87 \pm 1.55^{\mathrm{c}}$ & $36.92 \pm 0.82^{\mathrm{a}}$ & $33.20 \pm 1.11^{\mathrm{b}}$ \\
\hline Protein & $16.90 \pm 0.60^{\mathrm{b}}$ & $13.25 \pm 1.70^{\mathrm{a}}$ & $18.77 \pm 0.63^{\mathrm{c}}$ & $14.00 \pm 1.01^{\mathrm{a}}$ \\
\hline Fibre & $9.40 \pm 0.58^{\mathrm{a}}$ & $19.36 \pm 0.21^{\mathrm{c}}$ & $12.25 \pm 0.25^{\mathrm{b}}$ & $21.09 \pm 0.67^{\mathrm{d}}$ \\
\hline Fat & $29.05 \pm 0.07^{\mathrm{d}}$ & $22.64 \pm 0.03^{\mathrm{a}}$ & $26.82 \pm 0.02^{\mathrm{c}}$ & $26.45 \pm 0.03^{\mathrm{b}}$ \\
\hline Energy (Kcal/100g) & $528.33 \pm 1.04^{\mathrm{d}}$ & $490.38 \pm 0.22^{\mathrm{a}}$ & $513.10 \pm 0.96^{\mathrm{c}}$ & $511.20 \pm 0.83^{\mathrm{b}}$ \\
\hline
\end{tabular}

Values are expressed as means of triplicate determinations \pm SEM. Values along rows with different superscript are significantly different $(p<0.05)$. WMS: Watermelon soaked, WMG: Watermelon germinated, WMB: Watermelon boiled, WMR: Watermelon unprocessed

Table 2: Anti-nutritional composition of processed and unprocessed Citrullus lanatus seed flour

\begin{tabular}{|c|c|c|c|c|}
\hline Antinutrient $(\mathbf{m g} / \mathbf{1 0 0 g})$ & WMS & WMG & WMB & WMR \\
\hline Tannins & $18.92 \pm 0.13^{\mathrm{a}}$ & $31.40 \pm 0.13^{\mathrm{c}}$ & $27.92 \pm 0.11^{\mathrm{b}}$ & $33.68 \pm 0.32 \mathrm{~d}$ \\
\hline Phytate & $0.12 \pm 0.01^{\mathrm{b}}$ & $0.29 \pm 0.01^{\mathrm{c}}$ & $0.11 \pm 0.01^{\mathrm{a}}$ & $0.36 \pm 0.01^{\mathrm{d}}$ \\
\hline Oxalate & $0.18 \pm 0.01^{\mathrm{c}}$ & $0.14 \pm 0.01^{\mathrm{a}}$ & $0.17 \pm 0.00^{\mathrm{b}}$ & $0.23 \pm 0.01^{\mathrm{d}}$ \\
\hline Saponins & $2.45 \pm 0.03^{\mathrm{b}}$ & $2.32 \pm 0.04^{\mathrm{b}}$ & $0.64 \pm 0.01^{\mathrm{a}}$ & $3.46 \pm 0.03^{\mathrm{c}}$ \\
\hline Trypsin Inhibitor & $0.06 \pm 0.2^{\mathrm{b}}$ & $0.06 \pm 0.01^{\mathrm{b}}$ & $0.05 \pm 0.02^{\mathrm{a}}$ & $0.07 \pm 0.01^{\mathrm{c}}$ \\
\hline Cyanogenic Glycoside & $1.37 \pm 0.01^{\mathrm{b}}$ & $0.71 \pm 0.32^{\mathrm{a}}$ & $0.71 \pm 0.06^{\mathrm{a}}$ & $1.99 \pm 0.01^{\mathrm{c}}$ \\
\hline
\end{tabular}

Values are expressed as means of triplicate determinations \pm SEM. Values along rows with different superscript are significantly different $(p<0.05)$. WMS: Watermelon soaked, WMG: Watermelon germinated, WMB: Watermelon boiled, WMR: Watermelon unprocessed

Table 3: Amino acids levels of processed and unprocessed Citrullus lanatus (watermelon) seed flours.

\begin{tabular}{|c|c|c|c|c|c|}
\hline $\begin{array}{c}\text { Amino acids } \\
(\mathrm{g} / 100 \mathrm{~g})\end{array}$ & WMS & WMG & WMB & WMR & $\begin{array}{c}\text { FAOWHO } \\
(1993)\end{array}$ \\
\hline Histidine & $2.24 \pm 0.01^{\mathrm{d}}$ & $1.85 \pm 0.03^{a}$ & $2.00 \pm 0.01^{\mathrm{b}}$ & $2.17 \pm 0.02^{c}$ & 2.4 \\
\hline Isoleucine & $3.21 \pm 0.12^{\mathrm{b}}$ & $2.70 \pm 0.17^{a}$ & $2.81 \pm 0.06^{a}$ & $3.01 \pm 0.01^{b}$ & 4.2 \\
\hline Leucine & $6.10 \pm 0.06^{b}$ & $5.60 \pm 0.17^{a}$ & $5.81 \pm 0.12^{b}$ & $5.84 \pm 0.06^{b}$ & 4.9 \\
\hline Lysine & $4.75 \pm 0.12^{c}$ & $4.03 \pm 0.02^{a}$ & $3.92 \pm 0.02^{\mathrm{a}}$ & $4.45 \pm 0.03^{b}$ & 4.2 \\
\hline Methionine & $2.20 \pm 0.12^{a}$ & $2.00 \pm 0.29^{a}$ & $2.30 \pm 0.17^{a}$ & $2.13 \pm 0.02^{a}$ & 2.2 \\
\hline Phenylalanine & $4.00 \pm 0.29^{c}$ & $3.37 \pm 0.06^{\mathrm{a}}$ & $3.10 \pm 0.06^{\mathrm{a}}$ & $3.72 \pm 0.02^{b}$ & 2.8 \\
\hline Threonine & $4.22 \pm 0.01^{c}$ & $3.83 \pm 0.02^{b}$ & $3.61 \pm 0.06^{a}$ & $3.55 \pm 0.03^{a}$ & 4.0 \\
\hline Tryptophan & $0.93 \pm 0.02^{\mathrm{a}}$ & $1.23 \pm 0.05^{c}$ & $1.05 \pm 0.03^{b}$ & $1.07 \pm 0.02^{b}$ & \\
\hline Valine & $4.62 \pm 0.01^{b}$ & $4.10 \pm 0.17^{a}$ & $3.75 \pm 0.19^{\mathrm{a}}$ & $3.71 \pm 0.06^{a}$ & 4.2 \\
\hline Arginine & $10.83 \pm 0.06^{a}$ & $10.16 \pm 0.58^{a}$ & $10.41 \pm 0.01^{\mathrm{a}}$ & $10.20 \pm 0.15^{a}$ & 2.0 \\
\hline Cysteine & $2.42 \pm 0.01^{\mathrm{c}}$ & $2.36 \pm 0.06^{c}$ & $2.24 \pm 0.02^{b}$ & $1.94 \pm 0.02^{\mathrm{a}}$ & \\
\hline Glycine & $5.37 \pm 0.02^{d}$ & $4.82 \pm 0.01^{c}$ & $3.66 \pm 0.06^{\mathrm{a}}$ & $3.85 \pm 0.03^{b}$ & \\
\hline Proline & $4.90 \pm 0.23^{a}$ & $5.00 \pm 0.12^{a}$ & $4.50 \pm 0.12^{\mathrm{a}}$ & $4.60 \pm 0.23^{a}$ & \\
\hline Serine & $3.70 \pm 0.12^{\mathrm{a}}$ & $3.35 \pm 0.06^{\mathrm{a}}$ & $3.20 \pm 0.12^{a}$ & $4.00 \pm 0.58^{\mathrm{a}}$ & \\
\hline Tyrosine & $2.41 \pm 0.02^{b}$ & $2.06 \pm 0.01^{a}$ & $2.41 \pm 0.01^{b}$ & $2.10 \pm 0.06^{\mathrm{a}}$ & 4.1 \\
\hline Alanine & $3.37 \pm 0.06^{a}$ & $3.56 \pm 0.01^{a}$ & $3.87 \pm 0.06^{\mathrm{b}}$ & $4.52 \pm 0.15^{c}$ & \\
\hline Glutamic acid & $15.61 \pm 0.01^{b}$ & $15.29 \pm 0.06^{\mathrm{a}}$ & $16.65 \pm 0.03^{d}$ & $15.75 \pm 0.03^{c}$ & \\
\hline Aspartic acid & $8.00 \pm 1.15^{\mathrm{a}}$ & $8.68 \pm 0.01^{a}$ & $8.99 \pm 0.01^{a}$ & $8.75 \pm 0.03^{a}$ & 4.0 \\
\hline
\end{tabular}

Values are expressed as means of triplicate determinations \pm SEM. Values along rows with different superscript are significantly different $(p<0.05)$. WMS: Watermelon soaked, WMG: Watermelon germinated, WMB: Watermelon boiled, WMR: Watermelon unprocessed 


\subsection{Effect of processing methods on functional properties}

The value of WAC, BD.WAC was significant $(p<0.05)$ higher in soaked seed flour of Citrullus lanatus when compared with the values obtained from other processing methods. No significant differences $(p>0.05)$ was observed in OAC and EC of processed seed flours when compared to the unprocessed sample (Table 4). There was no significant difference $(p>0.05)$ in the swelling capacity of the Citrullus lanatus among the different processing methods (Figure 1). However, the soaked seed flour has the highest level of solubility at $60^{\circ} \mathrm{C}$ and $100^{\circ} \mathrm{C}$ when compared to the raw seed flour, the solubility rate in boiled and germinated watermelon seed flour were observed to be constant at $70^{\circ} \mathrm{C}, 80^{\circ} \mathrm{C}$ and $90^{\circ} \mathrm{C}$ (Figure 2)

Table 4: Functional properties of Citrullus lanatus seed flour under different processing methods

\begin{tabular}{|c|c|c|c|c|}
\hline Samples & WMS & WMG & WMB & WMR \\
\hline $\mathrm{BD}\left(\mathrm{g} / \mathrm{cm}^{3}\right)$ & $0.63 \pm 0.21^{b}$ & $0.59 \pm 0.14^{b}$ & $0.67 \pm 0.21^{a}$ & $0.48 \pm 0.21^{a}$ \\
\hline WAC(\%) & $33.33 \pm 0.82^{a}$ & $33.33 \pm 0.75^{a}$ & $33.33 \pm 0.78^{b}$ & $53.85 \pm 0.82^{b}$ \\
\hline $\mathrm{OAC}(\%)$ & $33.33 \pm 0.05^{a}$ & $33.33 \pm 0.13^{a}$ & $42.86 \pm 0.03^{b}$ & $33.33 \pm 0.05^{a}$ \\
\hline $\mathrm{FC}(\%)$ & $1.96 \pm 0.39^{b}$ & $1.96 \pm 0.18^{a}$ & $2.86 \pm 0.36^{c}$ & $6.67 \pm 0.32^{d}$ \\
\hline $\mathrm{FS}(\%)$ & $50.37 \pm 0.35^{b}$ & $50.37 \pm 0.01^{a}$ & $66.66 \pm 0.07^{d}$ & $57.14 \pm 0.04^{c}$ \\
\hline $\mathrm{EC}(\%)$ & $44.00 \pm 0.65^{c}$ & $43.33 \pm 0.47^{c}$ & $33.33 \pm 0.35^{b}$ & $26.66 \pm 0.67^{a}$ \\
\hline $\mathrm{ES}(\%)$ & $16.66 \pm 0.49^{a}$ & $46.15 \pm 0.48^{d}$ & $40.21 \pm 0.32^{c}$ & $30.05 \pm 0.49^{b}$ \\
\hline
\end{tabular}

Values are expressed as means of triplicate determinations \pm SEM. Values along rows with different superscript are significantly different $(p<0.05)$. WMS: Watermelon soaked, WMG: Watermelon germinated, WMB: Watermelon boiled, WMR: Watermelon unprocessed WAC: water absorption capacity, OAC: oil absorption capacity, BD: bulk density, EC: emulsion capacity, FC: foaming capacity, FS: foaming stability, ES: emulsion stability.

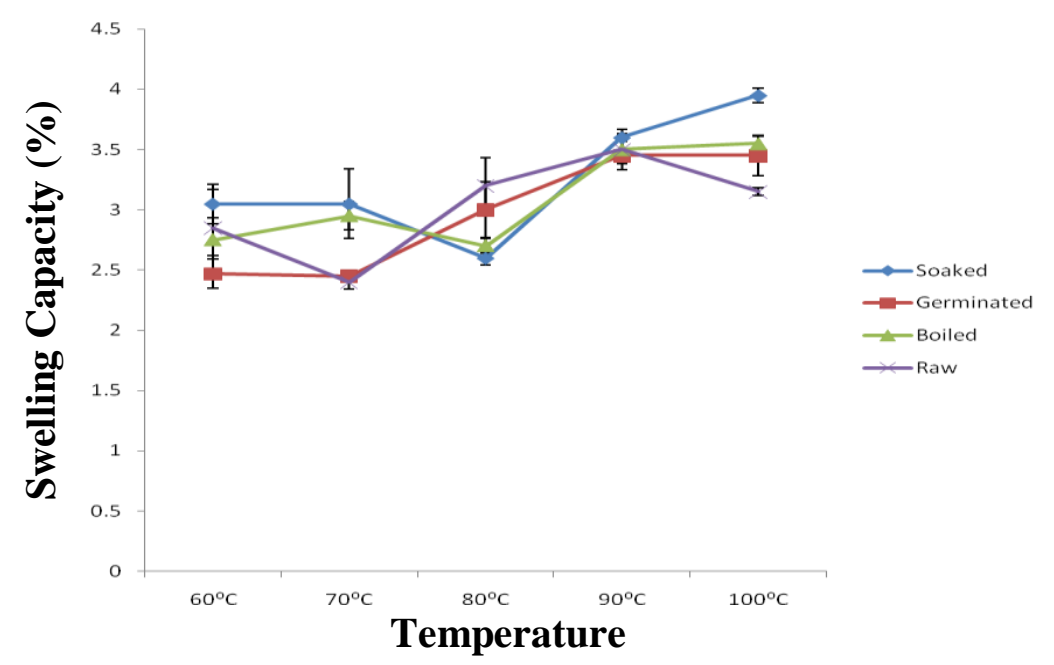

Figure 1: Swelling capacity of processed and unprocessed watermelon seed flour

\subsection{Discussions}

The shelf life of food products is important and is predicted by moisture content, higher moisture content naturally encourages organisms present in flour to grow, producing off odour and flavours. The result from this study (Table 1), showed a decrease in the moisture contents of all the seed flours in their processed state than in the unprocessed state when compared. This could be due to the drying technique efficiency with a prolonged drying period especially for the soaked and boiled seeds. For the germinated seeds, the lower moisture content observed might be as a result of water utilization for metabolic activities initiated by soaking. The lower moisture content obtained in this study suggest higher dry matter yield [23] which indicate the presence and quality of nutrients in a food sample [24] and these could enhance storage stability

The proximate composition of this research work showed that the different seed flours (processed and unprocessed) are good sources of protein. The protein contents reported in this study are higher when compared to the protein content of some commonly consumed seeds in Nigeria, 
namely coloccynthis citrullus, rapeseed and sunflower [25] but lower when compared to that of groundnut cake $50-55 \%$ [25].

In this study, germination, boiling and soaking tend to lower antinutrient content in all the seed flours when compared to the unprocessed seed flour (Table 2), this reduction in antinutrient content with respect to processing methods was also reported by a previous study [26] and could be as a result of leaching of the antinutrient in water especially phytate since is water-soluble. Tannins reduction during germination might be as a result of the formation of a hydrophobic association of tannins with seed proteins and enzymes while a decrease in phytate content during germination could be as a result of phytase activity as reported for other geminated cereals [26].

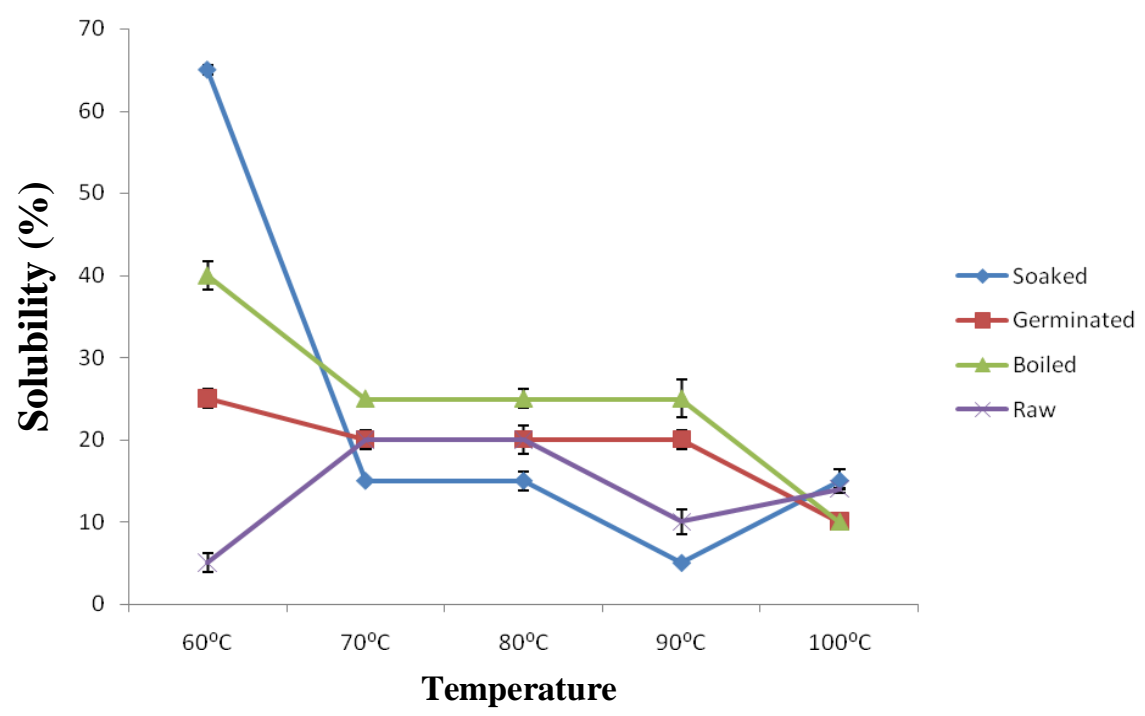

Figure 2: Solubility properties of processed and unprocessed watermelon seed flour

Water absorption capacity (WAC), serves as an index for the maximum amount of water a product can absorb and retain and is as well important in softening and increase digestibility [27], while oil absorption capacity (OAC) reveal if a product will be suitable for flavour enhancements and mouthfeel when used in food preparation [28]. In this study, these values were either higher or lower than the reports of other researchers, for instance, the bulk density of watermelon was higher when compared to soybean flour $\left(0.38 \mathrm{~g} / \mathrm{cm}^{3}\right)$ [29], but comparable to that of Bambara groundnut which ranges from $0.60 \mathrm{~g} / \mathrm{cm}^{3}$ to $0.75 \mathrm{~g} / \mathrm{cm}^{3}$ ) [30]. The bulk density of flour samples influences the amount and strength of packaging material; energy density, texture, and mouth feel [31]. For WAC, the values recorded in the present study (table 4) was higher in all the seed flours compared with soybeans $(1.12 \mathrm{~g} / 100 \mathrm{~g}$ ) reported in the previous study [32].
The foaming capacity (FC) of all the processed seed flours in this study are lower when compare to that of the boiled Moringa oleifera Lam seed flours, this result is similar to that reported in previous studies[32-33] where FC of boiled Moringa oleifera Lam seed flours is higher than that of kerting ground and rear cowpea flours. Similarly, the good foam stability recorded for the processed seed flour suggests that processed watermelon seed flours may be suitable for cakes baking and whipping topping where foaming is important [34].

The emulsion capacity and stability (EC and ES) are important parameters in the production of pastries, coffee whiteners and frozen desserts [35]. EC of all the seed flours ranges from $16.61 \%$ to $44.00 \%$ while ES ranges from $16.66 \%$ to $83.33 \%$, this suggests that the flour blends may be good emulsifying agents. This may be due to the presence of both the soluble and insoluble protein as well as other components such as polysaccharides (polysaccharides can also help in stabilizing 
the emulsion by increasing the viscosity of the system) [35].

Swelling power (SP) and solubility (S) provide evidence of the magnitude of the interaction between the starch chain within the amorphous and crystalline domain. SP and S of flours have been used to provide evidence for the association of binding forces within granules [36]. When an aqueous suspension of starch granules is heated; they become hydrated and swelling takes place.

Shimelis et al. [37] Classified starch to be highly swelling $\left(30 \%\right.$ or higher in $\left.95^{\circ} \mathrm{C}\right)$, moderately restricted swelling (16\% to $20 \%$ in $95^{\circ} \mathrm{C}$ ) or highly restricted swelling (below $16 \%$ in $95^{\circ} \mathrm{C}$ ). From this study, all the seed flours are in the highly restricted swelling category (below $16 \%$ in $95^{\circ} \mathrm{C}$ ) and this result is similar to that of Oke et al. [36] on yam flour. This low SC (figure 1) and S (figure 2) reported in this study would be desirable for the manufacture of value-added products such as noodles and composite blends with cereals and it suggests that all the seed flours could be good sources of nutrients to its consumers and bring about food security in developing countries. The low value of SP and $S$ of these seed flours might be due to proteinamylose complex formation.

Essential amino acids are amino acids that cannot be synthesized by the body, they can be gotten through diet, however, the quantity of a dietary protein is a measure of its essential amino acids which are required for growth and maintenance [38]. Non-essential amino acids are equally important as they also help in growth development. In table 3, soaking significantly increased the essential and non-essential amino acids except for tryptophan where a decrease was seen generally across the seed flours.

The increment seen in soaked seed flours of Citrullus lanatus might be as a result of the hydrolytic breakdown of nutrient components during soaking, this report is similar to the one reported by Guoyao et al. [39] in soaking of groundnuts, soybean and garbanzo. Leucine is the most abundant essential amino acid in all the seed flours while glutamic acid is the most abundant non-essential amino acid. On a general note, this study revealed that these seed flours are rich sources of amino acids. This suggests that these seed flours are nutritionally high-quality foods.

\subsection{Conclusion}

Results obtained from this study revealed that soaking and boiling can be used to improve the nutritional composition of watermelon seeds flour. This study also revealed that watermelon seeds contain some antinutrients which could be reduced by boiling and germination. Thus can be incorporated into diets since the seed possesses good nutritional properties.

Conflict of Interest: The author declared no conflict of interest exist

Ethical Approval: Not applicable

Authors contributions: The work was conducted in collaboration of all authors. All authors read and approved the final version of the manuscript.

Funding statement: no grant was given, it was a self-funded research

\section{Reference}

1. World Health Organization (2018) Malnutrition Fact Sheet, WHO Geneva, Switzerland

2. Olawuyi, Y. O. and Oyetola, F. (2020). Flour functionality, chemical and sensory properties of cookies from trifoliate yam flour-soybean blends. Agrosearch, 20(1):106-117

3. Fadare, O., Amare, M., Mavrotas, G., Akerele, D. and Ogunniyi, A. (2019) Mother's nutrition-related knowledge and child nutrition outcomes:Empirical evidence from Nigeria. PLoSONE14(2):e0212775

4. Kolawole, F.L., Balogun, M. A., Opaleke, D.O. and Amali, H.E. (2013). An evaluation of nutritional and sensory qualities of wheat Moringa cake. Agrosearch,13(1),87 -93.

5. Betty, T., Jacob, K., Agbenorhevi, F. D., Wireko-Manu, E. I., and Ompouma O.(2016) Watermelon Seeds as Food: Nutrient Composition, Phytochemicals and Antioxidant Activity. International Journal of Nutrition and Food Sciences. Vol. 5, No. 2, pp. 139-144.

6. Baker, T.P., Corwin, B. \& Jeft, L.W. (2012) Watermelon Bacterial Fruit 
Biotechnology. European Journal of Medicinal Plant; 1(4): 171-179.

7. Oyeleke, G.O, Olagunu, E.O. and Ojo, A. (2012). Functional and physicochemical properties of watermelon seeds and seed oil, Journal of Applied Chemistry.2: 29 31

8. Osman, A.M. (2007). Effect of different processing methods on nutrient composition, anti-nutritional factors and in vitro protein digestibility on Dolichos lablab bean (Lablab purpureus ( $L$ ) Sweet). Pakistan Journal of Nutrition. 6(4): 299303.

9. Vijayakumari, K., Siddhuraju, P. and Janardanan, K. (1995). Effect of various water treatments on certain antinutritional compounds in the tribal pulse, Dolichos lablab var vulgaris $L$. Plant Foods for Human Nutrition. 48: 17-29.

10. Romo-Parade, M.L., Simard, R.E. and Larrea-Renoso, S.S. (1985). Influence of germination, hixtamalization and fermentation on nutritional value of sorghum protein. Journal of Nutrition. 3: 125-132.

11. Ahamefule, F.O., Obua, B.E., Ukweni, I.A., and Amaka, R.A. (2008). Haematological and Biochemical Profile of Weaner Rabbits fed Raw or Processed Pigeon Pea Seed Meal Based Diets. African Journal of Agricultural Research, 3(4), 315-319.

12. Jimoh, W.A., Ajasin, F.O., Adebayo, M.D., Banjo, O.T., Rifhat, A.O., and Olawepo, K.D. (2014). Haematological Changes in the Blood of Clarias gariepinus fed Chrysophyllum albidum seed meal replacing maize. Journal of Fisheries and Aquatic Science, 9, 407-412.

13. Saulawa, L.A. Yaradua, A.I. and Shuaibu, L. (2014). Effect of Different Processing Methods on Proximate, Mineral and Anti Nutritional Factors Content of Baobab (Adansonia digitata) Seeds. Pakistan Journal of Nutrition, 13(6), 314-318

14. Kayembe, N.C.and Jansen C. (2013) Germination as a processing technique for soybeans in small-scale farming. South African Journal of Animal Science, 43 (No. 2)
15. AOAC, (Association of Official Analytical Chemists (2006).Official method of Analysis of Association of Official analytical Chemists, $18^{\text {th }}$ edition, W. Horwitz editor, Washington D.C.

16. Onwuka, G.I. (2005). Food analysis and Instrumentation theory and practice. $1^{\text {st }}$ edition, Napththali prints, Nigeria. 64 $67,98,140-145$.

17. AOAC, (2000). Official method of analysis of the Association of Official Analytical Chemistry, 17th Edn. Washinton D.C.

18. Sosulski, F.W., Garatt, M.O. and linkard A.E. (1976). Functional properties of ten legume flours. International Journal of Food Science and Technology. 9:66-69

19. Yasumatsu, K., Sawada, K., Maritaka, S., Toda, J., Wada, T. and Ishi, K. (1972). Whipping and emulsifying properties of soy bean products. Journal of Agricultural and Biological. Chemistry. 36:719-727.

20. Jones, D., Chinnaswamy, R., Tan, Y. and Hanna A. (2000). Physiochemical properties of ready-to-eat breakfast cereals. Cereal Foods World 45:164-168.

21. Okaka, J.C. \& Potter, N.N. (1977). Functional and storage properties of cow pea-wheat flour blends in bread making. Journal of Food Sciences. 42:828-833.

22. Narayana, K. \& Narsinga R.M.S. (1982). Functional properties of raw and heat processed winged bean (Psophocarpus tetragonolobus) flour. Journal of Food Science. 42:534-538.

23. Bamigboye, A. Y., Okafor A. C. and Adepoju O. T., (2010). Proximate and mineral composition of whole and dehulled Nigerian sesame seed. African Journal of Food Science Technology, 1: 71-75.

24. Nielsen, S.S. (2002). Introduction to chemical analysis of food. CBS Publishers 4596/1-A Daryagani, New Delhi 110032 (India), 95-115, 233-239.

25. Adesuyi, A.O. and. Ipinmoroti K.O, 2011. The nutritional and functional properties of the seed flour of three varieties of Carica papaya. Current Research in Chemistry. 3: 70-75. 
26. Adebayo SF (2014). Effect of Soaking Time on the Proximate, Mineral Compositions and Anti-nutritional Factors of Lima Bean.Food Science and Quality Management www.iiste.orgISSN 2 2246088 (Paper) ISSN 2225-0557 (Online)Vol.27.

27. Ijarotimi, O. S. and Oluremi, O. K. (2012): "Comparison between the amino acid, fatty acid, mineral and nutritional quality of raw, germinated and fermented African locust bean (Parkia biglobosa) flour. Journal Food Sciences and Nutrition Acta Scientiarum 11.2:151-165

28. Balogun IO, Olatidoye OP (2010). Functional properties of dehulled and undehulled velvet beans flour (Mucuna utilis). Journal of Biological Science and Bioconservation 2: 1-10

29. Edema M.O.,. Sanni L.O, and Sanni A.I. (2005), Evaluation of maize-soy-bean flour blends for sour dough maize bread production in Nigeria. African Journal of Biotechnology, 4 (9) pp. 911-918

30. Bernard, T., Aduni, U.A, and Bertrand T.F. (2016)Formulation and Nutritional Evaluation of Instant Weaning Foods Processed from Maize (Zea mays), Pawpaw (Carica papaya), Red Beans (Phaseolus vulgaris) and Mackerel Fish Meal (Scomber scombrus)." American Journal of Food Science and Technology,. vol.4, no. 5: 149-159.doi:10.12691/ajfst4-5-5.

31. Udensi, E. A., and Okoronkwo, K. A. (2006). Effects of fermentation and germination on the physicochemical properties of Mucuna cochinchinensis protein isolate. African Journal of Biotechnology , 5(10), 896-900.

32. Alfaro, M.J, Alvaraz, I, Khor, E.L. and Padika F.C. Functional properties of protein products from Barinus nut. American Journal of Clinical Nutrition. 2004;54:223-228.

33. Aremu, M. O., Olonisakin, A; Atolaye, B. O., \& Ogbu, C. F. (2006). Some nutritional and functional studies of Prosopis africana. Electronic Journal of Environmental, Agricultural and Food Chemistry, 5(6), 1640-1648.
34. Kaushal, P., Kumar, V. and Sharma, H.K. (2012). Comparative study of physicochemical, functional, anti-nutritional and pasting properties of taro (Colocasia esculenta), rice (Oryza sativa), pegion pea (Cajanus cajan) flour and their blends. LWT- Food Science and Technology. 48:59-68.

35. Abdel-Shafy, S. ; Nasr, S. M. ; AbdelRahman, H. H. \& Habeeb, S. M., 2011. Effect of various levels of dietary Jatropha curcas seed meal on rabbits infested by the adult ticks of Hyalomma marginatum marginatum I. Animal performance, antitick feeding and haemogram. Trop. Anim. Health Prod., 43 (2): 347-357

36. Oke, M.O., Awonorin, S. O. and Workneh, T. S. (2013). Effect of varieties on physicochemical and pasting characteristics of Water yam flours and starches. African Journal of Biotechnology, 12(11), 1250-1256.

37. Shimelis, A. E., Meaza, M., and Rakshit, S. (2006). Physico-chemical Properties, Pasting Behavior and Functional Characteristics of Flours and Starches from Improved Bean (Phaseolus vulgaris L.) Varieties Grown in East Africa. Agricultural Engineering International: the CIGR Ejournal. Manuscript FP 05 015, 8, 18-36.

38. Guoyao W., (2014). Dietary requirements of synthesizable amino acids by animals: a paradigm shift in protein nutrition. Journal of Animal Science and Biotechnology 5, 34

39. Bujang A. and Nurul A. T. (2014) Changes on Amino Acids Content in Soybean, Garbanzo Bean and Groundnut during Pre-treatments and Tempe Making. Sains Malaysiana 43(4): 551-55 